\title{
Evaluasi Administrasi Pelaksanaan Pemilu Serentak 2019 Terhadap Nilai-Nilai Pancasila
}

\author{
Lita Tyesta ALW \\ Fakultas Hukum, Universiats Diponegoro \\ Corespondent author: litatyestalita@yahoo.com
}

\begin{abstract}
The aim of this paper is to find out the administrative evaluation of the implementation of simultaneous elections in 2019 on the actualization of the values of Pancasila. Writing is an ingredient in the framework of participation in Focus Groups Discussion with the theme "Evaluation of the Implementation of the 2017 Election Law Against the Values of Pancasila" held by BPIP, Jakarta 5 to 7 August 2019, and arranged using the conceptual approach and factual approach. The results of the study indicate that the implementation of general elections in the future must be more planned and well-programmed so that things that become weaknesses in the simultaneous elections in 2019 do not occur. In the future, simultaneous elections must be carried out including: separating national and local elections; there must be an improvement in the recruitment and time management model especially for the organizers; Preparation of the final voter list should be cross-institutional related to population; A review of the provisions of the Presidential Threshold is required if the General Elections are still held simultaneously; Time management in the preparation of ballot distribution to the most remote, remote, most difficult, outermost areas, so that voting can be done simultaneously, including at the time of collection for ballot counting, and; Development of an accurate and trusted information technology system in the vote-counting process.
\end{abstract}

Keywords: Administrative Evaluation, Election Implementation, Pancasila Values,

\begin{abstract}
Abstrak
Tulisan bertujuan untuk mengetahui evaluasi administrasi pelaksanaan pemilu serentak tahun 2019 terhadap aktualisasi nilai nilai pancasila. Penulisan merupakan bahan dalam rangka keikutsertaan pada Focus Groups Discussion dengan tema "Evaluasi Implementasi UU Pemilu Tahun 2017 Terhadap Nilai-Nilai Pancasila“ yang diselenggarakan oleh BPIP, Jakarta 5 sampai dengan tanggal 7 Agustus 2019, dan disusun menggunakan pendekatan conceptual approach dan Factual Approach. Hasil kajian menunjukan bahwa pelaksanaan pemilihan umum ke depan harus lebih terencana dan terprogram dengan baik agar hal hal yang menjadi kelemahan pelaksanaan pemilu serentak tahun 2019 tidak terjadi. Kedepan pemilu serentak harus melakukan diantaranya: memisahkan Pemilu tingkat pusat dan tingkat daerah; harus dilakukan perbaikan model perekrutan dan manajemen waktu khususnya bagi penyelenggara;
\end{abstract}


Penyusunan daftar pemilih tetap sebaiknya lintas institusi terkait kependudukan; Wajib dilakukan tinjau ulang ketentuan Presidential Treshold apabila Pemilu tetap dilaksanakan secara serentak; Manajemen waktu pada persiapan distribusi surat suara ke pelosok, wilayah terjauh, terpencil, tersulit, terluar, sehingga pemungutan suara dapat dilakukan serentak waktunya, termasuk pada saat pengumpulan untuk penghitungan surat suara, dan; Pengembangan sistem teknologi informasi yang akurat dan terpercaya dalam proses penghitungan suara.

Kata Kunci: Evaluasi Administratif, Pelaksanaan Pemilu, Nilai Nilai Pancasila,

\section{A. Pendahuluan}

Bagi negara demokrasi modern pemilihan umum merupakan mekanisme utama yang harus ada dalam tahapan penyelenggaraan negara dan pembentukan pemerintahan. Pemilu sebagai bentuk nyata dari kedaulatan rakyat serta wujud paling konkrit partisipasi rakyat dalam penyelenggaraan negara. Oleh karena itu sistem dan penyelenggaraan pemilu selalu menjadi perhatian utama, pemerintahan dari oleh dan untuk rakyat melalui penataan sistem dan kualitas penyelenggaraan pemilu. Pelaksanaan Pemilu Tahun 2019 meninggalkan banyak catatan dalam pelaksanaanya. Studi Campbell (1960) menghipotesiskan pemilu serentak menyebabkan dua gejala, yaitu gelombang penurunan dan pelonjakan. Pemilu serentak hanya berfungsi sebagai "stimulasi politik" untuk meningkatkan partisipasi.

Diantara catatan yang paling mengemuka adalah adanya masa kampanye yang cukup panjang. Sehingga masa kampanye yang cukup panjang, yaitu sekitar tujuh (7) bulan mulai dari tanggal 23 bulan September 2018 s/d 23 bulan april 2019. Tidak hanya waktunya yang cukup panjang, akan tetapi terdapat problem diantara pelaksanaan pelaksanaan pemilu Tahun 2019. Tulisan dengan judul "Evaluasi Administratif Pelaksanaan Pemilu 2019 Terhadap Nilai-Nilai Pancasila” ini merpakan tinjauan singkat tentang pelaksanaan Pemilu 2019 dari aspek aktulisasi nilai nilai pancasila.

Untuk menguraikan lebih jauh tentang pelaksanaan pemilu 2019, maka akan diuraikan tentang 1). Kelemahan yang muncul pasca pelaksanaan pemilu tahun 2019; 2). Alasan utama yang melatar belakangi pelaksanaan pemilu 2019, dan ; 3). Masukan terhadap pelaksanaan pemilu serentak di masa yang akan datang.

\section{B. Pembahasan}

Pada pembahasan ini akan dibahasan hal hal sebagai berikut 1). Kelemahan yang muncul pasca pelaksanaan pemilu tahun 2019; 2). Alasan utama yang melatar belakangi 
pelaksanaan pemilu 2019, dan; 3). Masukan terhadap pelaksanaan pemilu serentak di masa yang akan datang.

\section{Alasan Pemilu Serentak Tahun 2019}

Pilpres 2019 menjadi bagian dari pemilihan umum (Pemilu) serentak pertama di Indonesia dalam sejarah. Selain memilih Presiden dan Wakil Presiden, Pemilu 2019 juga menjadi momen bagi rakyat Indonesia untuk memilih anggota DPR, DPD, DPRD Provinsi, dan DPRD Kabupaten/Kota. Sejarah digelarnya pemilu serentak berawal usulan Koalisi Masyarakat untuk Pemilu Serentak. Pada 2013 Koalisi Masyarakat untuk Pemilu Serentak menggugat Undang-Undang (UU) Nomor 42 Tahun 2008 tentang Pilpres ke Mahkamah Konstitusi (MK).

MK mengabulkan dan mengeluarkan putusan uji materi (judicial review) untuk UU yang digugat Koalisi Masyarakat untuk Pemilu Serentak tersebut pada Mei 2013 kendati baru resmi disidangkan pada Januari 2014. Penerapan pemilu serentak bisa dilakukan pada 2019, bukan untuk Pemilu 2014 dengan alasan waktu yang terlalu mepet. Koalisi Masyarakat untuk Pemilu Serentak pun mempertanyakan kebijakan MK tersebut. Gayung bersambut, KPU sebagai penyelenggara pemilu menilai bahwa pemilus serentak lebih efiesn dan efektif. Adapun alasan diadakanya pemilu serentak adalah berdasarkan alasan sebagai berikut:

\section{a). Penyelenggaraan Pemilu Serentak Lebih Efisien dan Murah.}

Berdasarkan perhitungan anggota KPU saat itu, Ferry Kurnia Rizkiyansyah, penyelenggaraan pemilu serentak bisa menghemat anggaran $\mathrm{Rp} 5$ sampai $\mathrm{Rp} 10$ triliun. Sedangkan berdasarkan perhitungan Anggota DPR F-PDIP Arif Wibowo, pemilu serentak mampu menghemat dana sekitar Rp 150 triliun, atau sepersepuluh APBN dan APBD. Pada akhirnya, MK mengabulkan sebagian gugatan tersebut. Alih-alih menghemat anggaran Nyatanya biaya pemilu serentak ternyata jauh lebih mahal dibandingkan dengan biaya pemilu sebelum-sebelumnya. Hal ini terbukti dari pengalokasian anggaran sebesar Rp 24,8 triliun untuk penyelenggaraan Pemilu dan Pilpres 2019. Alokasi anggaran ini naik 3 persen atau bertambah Rp 700 miliar dibanding biaya Pemilu dan Pilpres 2014 lalu yang mencapai Rp 24,1 triliun. Juga sebelumnya pada tahun 2018, pemerintah telah mengalokasikan anggaran pemilu sebesar Rp 16 triliun. 


\section{b). Memakan Waktu Panjang dan Melelahkan.}

Buntut panjang dari hal ini adalah banyaknya korban jiwa yang berjatuhan akibat kelelahan mengurus pagelaran akbar ini. Komisi Pemilihan Umum (KPU) merilis total petugas KPPS yang sakit dan meninggal dunia saat menjalankan tugas di Pemilu serentak 2019. Petugas KPPS yang sakit berjumlah 883; Meninggal dunia berjumlah 144 orang.

\section{Kelemahan Yang Muncul Pasca Pelaksanaan Pemilu Tahun 2019}

Pada pelaksanaan pemilu tahun 2019 yang lalu, terdapat kelemahan yang muncul pasca pelaksanaan yaitu diantarannya. Kelemahan kelemahan tersebut bukan hanya bersumber dari regulasi yang ditetapkan oleh Komisi Pemilihan Umum, akan tetapi juga muncul karena peran serta masyarakat minim terhadap penyelenggaraan pemilu. Dinatara permasalahan yang muncul tersebut adalah sebagai berikut:

a) Tahap pencalonan : apakah sudah pas dengan Presidential Treshold

b) Masa kampanye yang cukup panjang (7) bulan mulai dari 23 September $2018 \mathrm{~s} / \mathrm{d}$ 23 April 2019, menimbulkan banyak problem,

c) Pemungutan suara : terlalu banyak caleg yang dipilih cukup membingungkan pemilih

d) Peran media yang kurang netral

e) Akses informasi yang terbatas bagi pemilih diluar domisili

f) Konflik sosial, keterbatasan waktu dalam pelaksanaan pemungutan suara dan penghitungan, panjangnya waktu penghitungan suara pasca pemungutan suara (kurang manusiawi)

g) Masa kampanye calon anggota DPR, DPD dan DPRD serta pasangan capres dan cawapres dimulai sejak 23 September 2018 hingga 13 April 2019 (7 Bulan ) ternyata banyak menimbulkan keresahan yang berupa konflik antar kubu paslon ;

h) Sistem serentak pilpres dengan pileg pusat dan daerah, terlihat pilpres lebih dominan dibanding pileg

i) Masa Pencalonan, adanya Presidential threshold, apakah sudah pas dengan nilai keadilan mengingat sistem ini sangat dipengaruhi oleh perolehan kursi di legislatif yang didasarkan pada hasil pemilu sebelumnya.

Namun disisi lain, tidak semua tahapan pemilu mengalami problem, seperti yang duraikan tersebut, akan tetapi problem juga muncul hanya di beberapa tahapan yaitu sebagaimana tabel sebagai berikut. 


\begin{tabular}{|c|c|c|}
\hline NO & TAHAPAN PEMILU & EVALUASI \\
\hline 1 & Perencanaan Program dan Anggaran & Transparan, adil, \\
\hline 2 & Penyusunan PKPU & Transparan \\
\hline 3 & Sosialisasi & $\begin{array}{l}\text { Berjenjang, berkesinambungan dan melibatkan berbagai unsur } \\
\text { terkait }\end{array}$ \\
\hline 4 & $\begin{array}{l}\text { Pendaftaran dan Verifikasi Peserta } \\
\text { Pemilu }\end{array}$ & Transparan \\
\hline 5 & $\begin{array}{l}\text { Penyelesaian sengketa penetapan } \\
\text { parpol dan peserta pemilu }\end{array}$ & Transparan dan adil \\
\hline 6 & Pembentukan Badan Penyelenggara & $\begin{array}{l}\text { Transparan, professional, proposional, adil termasuk } \\
\text { mekanisme, beban kerja, usia, honor }\end{array}$ \\
\hline 7 & $\begin{array}{l}\text { Pemutahiran data pemilih dan } \\
\text { penyusunan data pemilih }\end{array}$ & Transparan adil dan bekeriasama dengan pihak terkait \\
\hline 8 & Penyusunan Daftar Pemilih LN & Transparan, melibatkan pihak kedutaan dan pihak terkait \\
\hline 9 & Penataan dan Penetaan Dapil & \\
\hline 10 & $\begin{array}{l}\text { Pencalonan anggota DPR, DPD, DPRD } \\
\text { Prov/Kab/Kota } \\
\text { Presiden dan wakil pres }\end{array}$ & $\begin{array}{l}\text { Adanya Parlement Treshold dan Presidentiil threshold? } \\
\text { dengan system Serentak? }\end{array}$ \\
\hline 11 & Logistik & $\begin{array}{l}\text { Transparan, mengantisipasi lebih awal bagi daerah terpencil, } \\
\text { tersulit, terjauh; }\end{array}$ \\
\hline 12 & Kampanye calon & $\begin{array}{l}\text { Waktu } 7 \text { bulan, perlu ditinjau ulang, terlalu lama, beaya cukup } \\
\text { besar, rawan konflik, muculnva hoax } 2 \text { yang membuat makin } \\
\text { tajam konflik di masyarakat khususnya untuk Pilpres dan Wakil }\end{array}$ \\
\hline 13 & Masa Tenang & \\
\hline 14 & $\begin{array}{l}\text { Pemungutan Suara dan Penghitungan } \\
\text { suara }\end{array}$ & $\begin{array}{l}\text { Ancaman money politik, model pengawasan yang efektif } \\
\text { effisien, penggunaan IT yang ketat dan canggih }\end{array}$ \\
\hline 15 & Rekap basl penghitungan suara & Transparan tetapi ketat supaya tidak ada manipulasi data \\
\hline 16 & Penyelesaian Sengketa Pres dan wakil & \\
\hline 17 & Penetapan Pres dan Wakil Pres & \\
\hline 18 & $\begin{array}{l}\text { Penetapan Perolehan Kursi dan Calon } \\
\text { Terpilih tanpa PHPU }\end{array}$ & \\
\hline 19 & $\begin{array}{l}\text { Penetapan Perolehan Kursi dan calon } \\
\text { terpilih Pasca Putusan MK }\end{array}$ & \\
\hline 20 & Peresmian keanggotaan & \\
\hline 21 & Pengucapan Sumpah dan Janji & \\
\hline
\end{tabular}

\section{Bagan : Evaluasi Tahapan Pemilihan Umum Serentak 2019}

\section{Simpulan}

Berdasarkan uraian singkat tersebut maka dapat disimpulkan bahwa: 1). Meninjau ulang sistem serentak, memisahkan Pemilu tingkat pusat dan tingkat daerah. 2). Perbaikan model perekrutan dan manajemen waktu khususnya bagi penyelenggara Pemilu ditingkat KPPS. 3). Penyusunan DPT sebaiknya lintas institusi terkait kependudukan, 4). Meninjau ulang ketentuan Presidential Treshold apabila Pemilu tetap dilaksanakan secara serentak. 5). Manajemen waktu pada persiapan distribusi surat suara ke pelosok, wilayah terjauh, terpencil, tersulit, terluar, sehingga pemungutan suara dapat dilakukan serentak waktunya, termasuk pada saat pengumpulan untuk penghitungan surat suara. 6). Pengembangan sistem teknologi informasi yang akurat dan terpercaya dalam proses penghitungan suara.

\section{Daftar Pusataka}


A. Mukthie Fadjar, "Pemilu Yang Demokratis dan Berkualitas: Penyelesaian Hukum Pelanggaran Pemilu dan PHPU", Jurnal Konstitusi, Vol. 6 No. 1, April 2009

Ahmadi. 2015. ANALISIS KONSTRUKSI HUKUM KONSTITUSIONALITAS. Jurnal Konstitusi, Volume 11, Nomor 3, September 2014517

I Dewa Made Putra Wijaya, "Mengukur Derajat Demokrasi Undang-Undang Nomor 42 Tahun 2008 tentang Pemilihan Umum Presiden dan Wakil Presiden”, Jurnal IUS, Vol. II Nomor 6 Desember 2014

Janedri M. Ghaffar. 2012. Politik Hukum Pemilu. Jakarta: Konstitusi Pres

Janpatar Simamora. 2014. Menyongsong Pemilu Serentak. Jurnal Rechstvinding Volume 3 Nomor 1 April 2014

Jimly Asshiddiqie. 2010. Pengantar Ilmu Hukum Tata Negara. Jakarta: PT Raja Grafindo Utama

Kacung Marijan, Sistem Politik Indonesia. Jakarta: Kencana, 2010.

Mardian Wibowo, "Menakar Konstitusionalitas sebuah Kebijakan Hukum Terbuka dalam Pengujian Undang-Undang”, Jurnal Konstitusi, Volume 12 Nomor 2, Juni 2015

Miriam Budiarjo, Dasar-Dasar Ilmu Politik, Jakarta: Gramedia, 2008.

Nazaruddin, "Kebijakan Multipartai Sederhana Dalam Undang-Undang Pemilu”, Jurnal Konstitusi, Volume 1 Nomor 1, Juni 2009

Sigit Pamungkas, Perihal Pemilu. 2009. Yogyakarta: Laboratorium Jurusan Ilmu Pemerintahan dan Jurusan Ilmu Pemerintahan Fisipol UGM

Sodikin, "Pemilu Serentak (Pemilu Legislatif dengan Pemilu Presiden dan Wakil Presiden) dan Penguatan Sistem Presidensiil”, Jurnal Rechtsvinding, Vol. 3 No. 1, April 2014

Syamsuddin Haris, Dkk. 2014. Pemilu Nasional Serentak 2019. Electoral Research Institute - Lembaga Ilmu Pengetahuan Indonesia. 